\begin{abstract}
Median length at maturity was determined for Pacific angel sharks (Squatina californica) captured incidentally in the artisanal elasmobranch fishery in the Gulf of California in Mexico. A total of 306 Pacific angel sharks (192 females and 114 males) were analyzed. The size of the females ranged between 23 and $100 \mathrm{~cm}$ total length (TL), whereas males ranged between 25 and $99 \mathrm{~cm}$ TL. The maturity stages of both females and males were determined by using the development of internal and external organs. The results of analysis of covariance reveal a significant effect of sex $(P<0.001)$ on length at maturity. A binary logistic regression was applied for each sex to estimate the length at which half of the individuals were considered mature $\left(L_{50}\right)$. For females, $L_{50}$ was $74.41 \mathrm{~cm}$ TL $(95 \%$ confidence interval [CI]: 72.81-76.00 cm TL), and the steepness coefficient $(\Phi)$ was 1.43 (95\% CI: $0.84-2.42)$. For males, $L_{50}$ was $77.82 \mathrm{~cm}$ TL (95\% CI: $75.66-79.97 \mathrm{~cm} \mathrm{TL})$, and the $\Phi$ was 3.08 (95\% CI: $1.98-4.77$ ). The maturity ogive produced by using a logistic function is suitable to represent the development pattern of this species because it describes maturity as a gradual process.
\end{abstract}

Manuscript submitted 28 October 2019. Manuscript accepted 30 October 2020. Fish. Bull. 118:359-364 (2020).

Online publication date: 11 December 2020. doi: 10.7755/FB.118.4.5

The views and opinions expressed or implied in this article are those of the author (or authors) and do not necessarily reflect the position of the National Marine Fisheries Service, NOAA.

\title{
Length at maturity of the Pacific angel shark (Squatina californica) in the artisanal elasmobranch fishery in the Gulf of California in Mexico
}

\author{
J. Fernando Márquez-Farías \\ Email address for contact author: fmarquez@uas.edu.mx \\ Facultad de Ciencias del Mar \\ Universidad Autónoma de Sinaloa \\ Paseo Claussen s/n \\ Col. Los Pinos \\ 82000 Mazatlán, Sinaloa, Mexico
}

The Pacific angel shark (Squatina californica) belongs to the family Squatinidae and inhabits the eastern Pacific Ocean. Its geographical distribution is discontinuous: from southern Alaska to the Gulf of California (GOC) in Mexico and from Ecuador to Chile (Compagno et al., 2005). This species is a nocturnal opportunistic predator of demersal fish species (Pittenger, 1984; Fouts and Nelson, 1999). In California, this species has been found in shallow waters at depths of 3-46 m, whereas in the GOC it has been observed at a depth of $183 \mathrm{~m}$. This species has been found buried in muddy and sandy bottoms. It also has been observed around rocks and in kelp forests (Compagno, 1984). The demography of the northern population off California has been studied, and the low productivity of this population has been modeled (Cailliet et al., 1992). The low productivity of this species is consistent with the characteristics of elasmobranchs that make them susceptible to overfishing: late maturity, low fecundity, and long life (Walker, 1998).

The capture of Pacific angel sharks is mostly incidental in the artisanal elasmobranch fishery and the finfish trawl fishery both in the GOC and on the Pacific coast of the Baja California
Peninsula (BCP) in Mexico. Biological information about the Pacific angel shark in Mexico is fragmented and limited to a few studies on trophic ecology and reproduction (Escobar-Sánchez et al., 2006, 2011; Romero-Caicedo et al., 2016). Using mitochondrial DNA, Ramírez-Amaro et al. (2017) reported genetic differences between specimens from the GOC and Pacific coast of the BCP, validating previous observations of life history differences between specimens from these areas (Villavicencio-Garayzar, 1996). Similarly, Márquez-Farías (2007) found maximum lengths and lengths at maturity for the population of shovelnose guitarfish (Pseudobatus productus) in the GOC that are different from those reported for the population along the Pacific coast of the BCP (Villavicencio-Garayzar, 1995).

Because of its historical exploitation rates and vulnerability, the Pacific angel shark is classified as near threatened on the IUCN Red List of Threatened Species (Cailliet et al., 2016). The significant fishing effort in the elasmobranch fishery of the GOC (Bizzarro et al., 2007) makes understanding the life history and population dynamics of this species essential to identification of strategies for its future management. 
The objective of this study was to estimate median length at maturity $\left(L_{50}\right)$ of the Pacific angel shark in the eastern GOC. Differences in life history characteristics have important management implications if they result in different population responses to fishing pressure.

\section{Materials and methods}

The artisanal elasmobranch fisheries of Sonora and Sinaloa, Mexico (Fig. 1), operate open-hulled fiberglass boats that are 5.5-7.6 $\mathrm{m}$ long and have outboard motors with 55-115 hp. Pacific angel sharks were collected at fishery landings during 1998-2005 (for details, see Bizzarro et al., 2009). Length, sex, and maturity stage of specimens were recorded. Total length (TL) was measured in centimeters from the tip of the rostrum to the end of the stretched caudal fin. Length-frequency distributions were constructed to examine the structure of the sample. Normality of length distributions was verified by using the KolmogorovSmirnov (K-S) test. If normality data were rejected, the nonparametric Mann-Whitney test was used to compare mean lengths of each sex. A chi-square test was used to compare the observed sex ratio of the entire sample and the

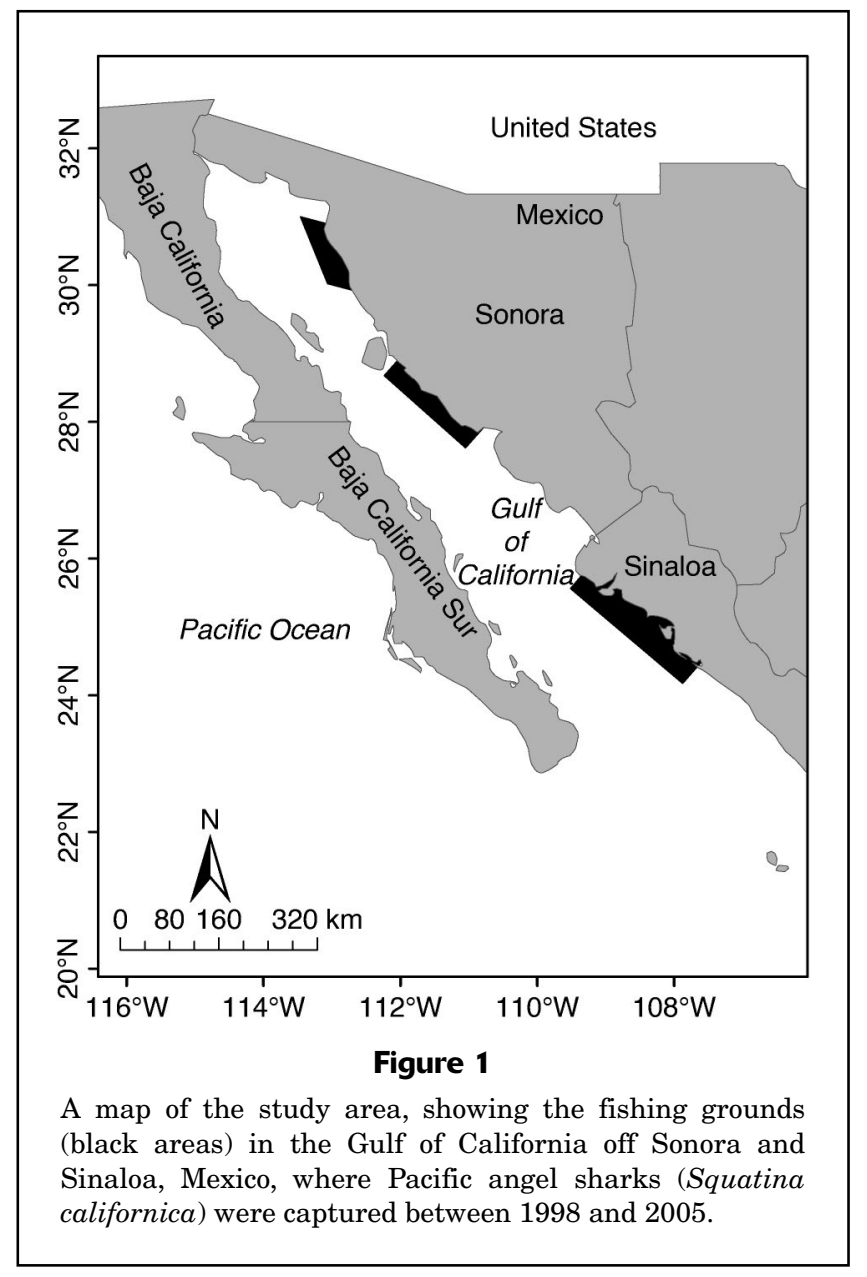

ratio of maturity stages (immature to mature) against the expected value of 1:1. Reproductive status was assessed through macroscopic examination following Clark and von Schmidt (1965) and Castro (2000). Mature males had hardened claspers that could rotate from the base by directing the claspers anteriorly on the inner side of the shark. The inner clasper length was measured from the point of insertion of the clasper to the clasper tip. The clasper length was plotted against TL to show how the clasper grew as an individual approached maturity. Females were considered mature when they had ripe oocytes ( $>20 \mathrm{~mm}$ in diameter) and a thickened uterus or when they were pregnant. Histograms and box plots of lengths by maturity stage were constructed to identify outliers.

For statistical treatment, the classification of maturity stages used 0 for immature individuals and 1 for mature individuals. Binary logistic regression between TL and maturity data was applied to estimate the regression coefficients $a$ and $b$. The significance of the difference in maturity stage between sexes was tested with an analysis of covariance by applying a general linear model with a significance level of 0.01 . With the coefficients $a$ and $b$, the proportion of mature sharks by length was determined by using the following logistic function (maturity ogive):

$$
P m_{\mathrm{TL}}=\frac{1}{1+\exp \left[-\frac{T L-L_{50}}{\Phi}\right]},
$$

where $P m=$ the proportion of mature fish given the length (TL);

$L_{50}=$ the median length of the sample when half of the individuals had reached maturity $\left(L_{50}=a / b\right)$; and

$\Phi=$ the steepness of the model $\left(\Phi=L_{50} / a\right)$.

All the parameters and their 95\% confidence intervals (CIs) were estimated with Minitab ${ }^{1}$, vers. 19.0 (Minitab, State College, PA).

\section{Results}

A total of 306 Pacific angel sharks (192 females and 114 males) were measured $\left(\chi^{2}=19.9, P<0.05\right)$. The mean length for females was $72.91 \mathrm{~cm}$ TL (standard deviation [SD] 16.88 ) with a range of $23-100 \mathrm{~cm}$ TL; the mean length for males was $80.32 \mathrm{~cm}$ TL (SD 13.32) with a range of 25-99 cm TL (Fig. 2A). For both sexes, the length distributions had maximum frequencies in the length class of 85-90 cm TL, a class that mostly corresponds with mature individuals (Fig. 2, B and C). Results of analysis of the normality of length distributions with the $\mathrm{K}-\mathrm{S}$ test indicate non-normal distributions of length for males $(\mathrm{K}-\mathrm{S}$ test: $D=0.209, P<0.01)$ and females (K-S test: $D=0.174$, $P<0.01)$. The nonparametric test revealed significant

\footnotetext{
${ }^{1}$ Mention of trade names or commercial companies is for identification purposes only and does not imply endorsement by the National Marine Fisheries Service, NOAA.
} 


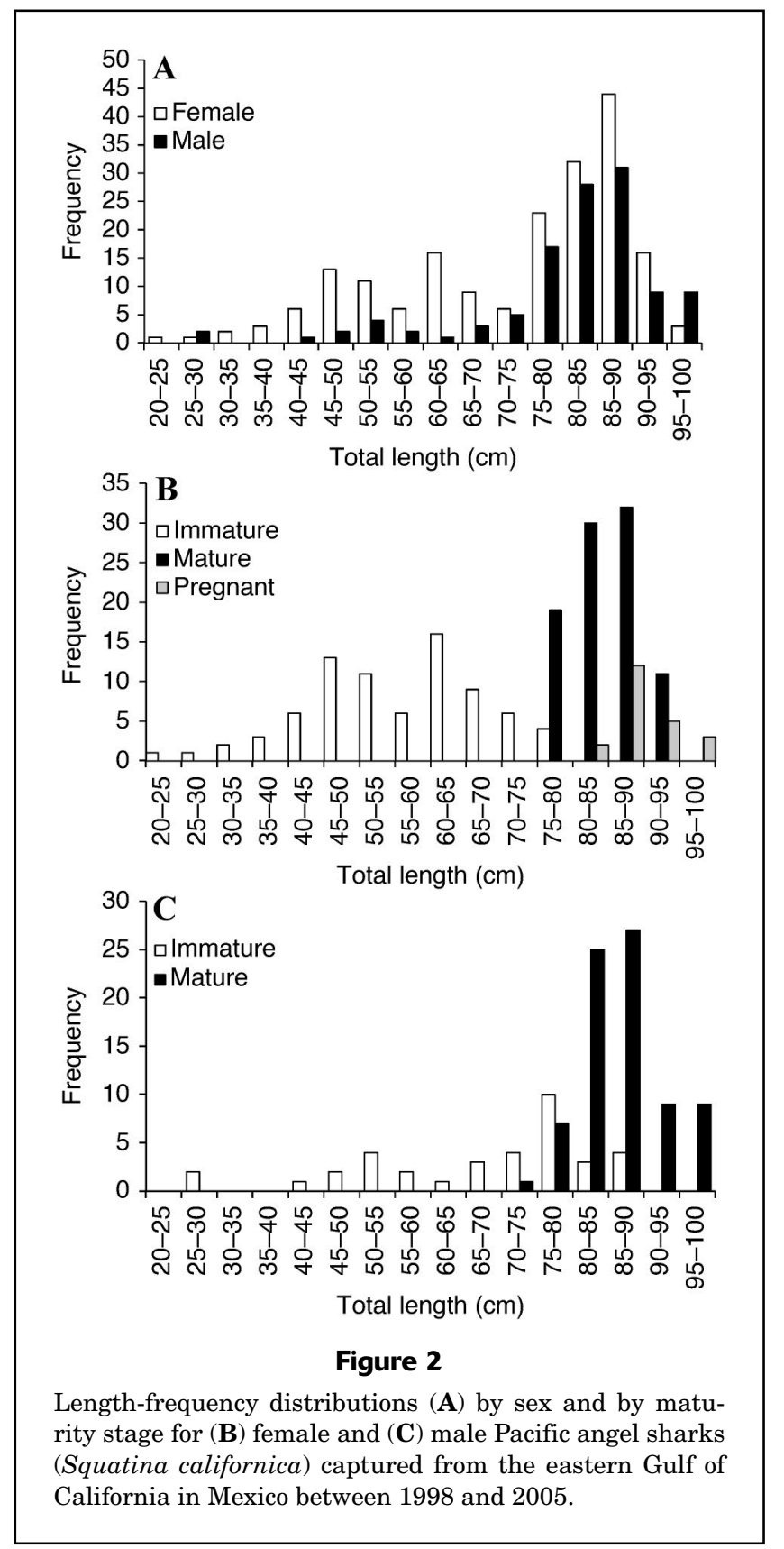

differences in mean length by sex for the Pacific angel sharks captured in the GOC (Mann-Whitney test: $U=26,818, P=0.001$ ). The mean length for mature females was $84.83 \mathrm{~cm}$ TL (SD 4.83) with a range of $75-100 \mathrm{~cm} \mathrm{TL}$ (number of specimens $[n]=114$ ). The diameters of the largest oocytes were $20-60 \mathrm{~mm}$ and, in pregnant females, ranged between 26 and $50 \mathrm{~mm}$ (Fig. 3A). The mean length of mature males was $86.18 \mathrm{~cm}$ TL (SD 5.54) with a range of 73-99 cm TL ( $n=78)$; clasper lengths ranged from 10 to $30 \mathrm{~mm}$ (Fig. 3B). Length ranges and maturity condition by sex are presented in Table 1 and Figure 4.

The analysis of covariance from the binary logistic regression revealed a significant effect of $\operatorname{sex}\left(\chi^{2}=14.9\right.$,

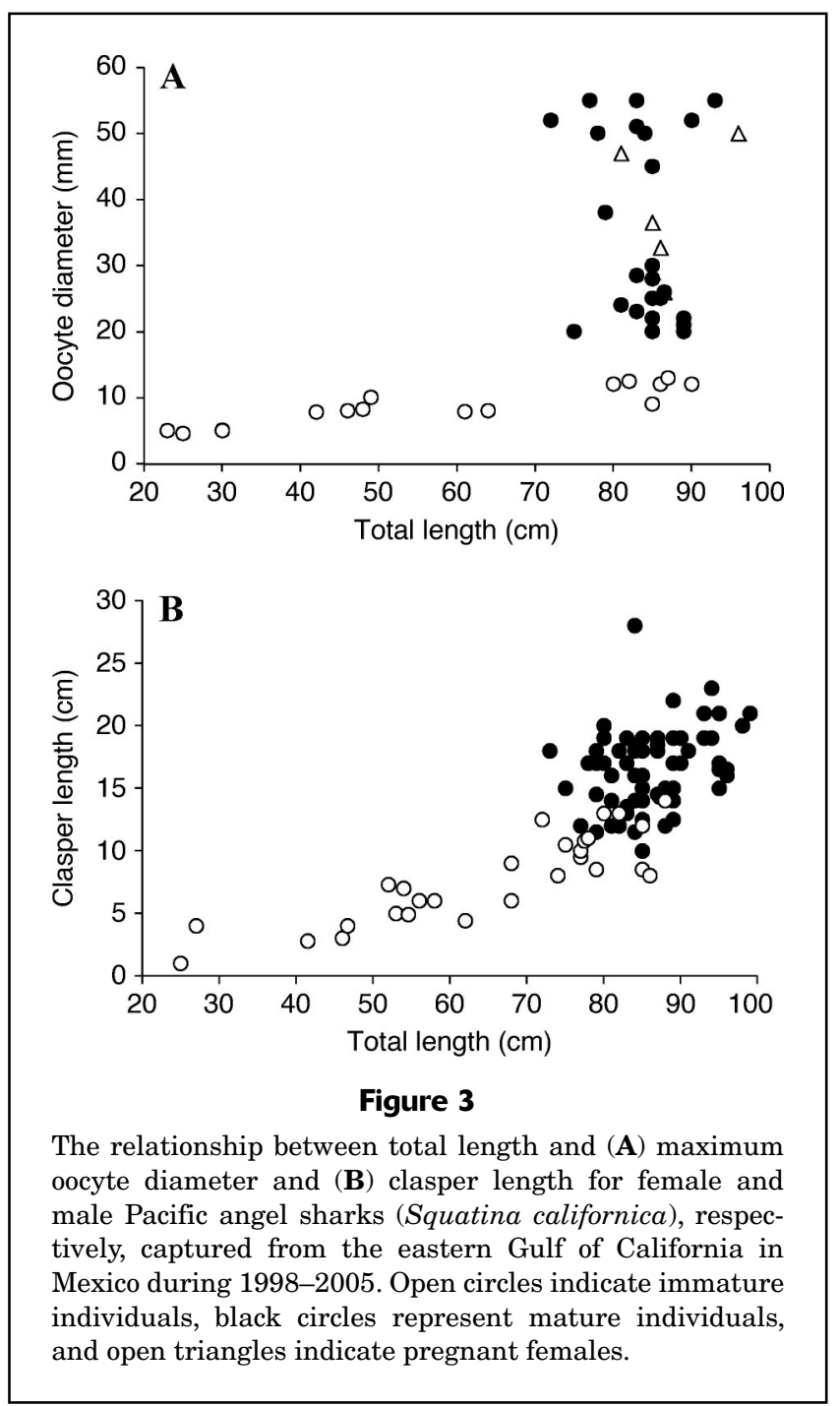

$\mathrm{df}=1, P<0.001)$. The model explained $75.0 \%$ of the variance. The contribution of TL to variance was $71.5 \%$, and sex explained $3.7 \%$ of the variance. The coefficients of the binary logistic regression for females $(a=-51.95, b=0.698)$ were used in the logistic function to describe the estimated proportion of mature fish by length. For females, the $L_{50}$ was $74.41 \mathrm{~cm} \mathrm{TL}$ (95\% CI: 72.81-76.00 cm TL), and the $\Phi$ was 1.43 (95\% CI: 0.84-2.42) (Fig. 5A). For males, the regression coefficients $(a=-25.27, b=0.3247)$ yielded a $L_{50}$ of $77.82 \mathrm{~cm}$ TL (95\% CI: $75.66-79.97 \mathrm{~cm} \mathrm{TL})$ and a $\Phi$ of 3.08 (95\% CI: 1.98-4.77) (Fig. 5B).

\section{Discussion}

The results of this study, conducted on the coasts of Sonora and Sinaloa, indicate differences between the lengths of Pacific angel sharks in the GOC and those of individuals along the Pacific coast of the BCP. In general, individuals from the Pacific coast of the $\mathrm{BCP}$ grow larger than those 


\section{Table 1}

Length-frequency distributions, by sex and maturity stage, for Pacific angel sharks (Squatina californica) captured in the eastern Gulf of California in Mexico between 1998 and 2005.

\begin{tabular}{|c|c|c|c|c|c|c|c|c|c|}
\hline \multirow{2}{*}{$\begin{array}{l}\text { Total } \\
\text { length }(\mathrm{cm})\end{array}$} & \multicolumn{3}{|c|}{ Female } & \multicolumn{3}{|c|}{ Male } & \multicolumn{3}{|c|}{ Both sexes } \\
\hline & Immature & Mature & Total & Immature & Mature & Total & Immature & Mature & Total \\
\hline $20-25$ & 1 & 0 & 1 & 0 & 0 & 0 & 1 & 0 & 1 \\
\hline $25-30$ & 1 & 0 & 1 & 2 & 0 & 2 & 3 & 0 & 3 \\
\hline $30-35$ & 2 & 0 & 2 & 0 & 0 & 0 & 2 & 0 & 2 \\
\hline $35-40$ & 3 & 0 & 3 & 0 & 0 & 0 & 3 & 0 & 3 \\
\hline $40-45$ & 6 & 0 & 6 & 1 & 0 & 1 & 7 & 0 & 7 \\
\hline $45-50$ & 13 & 0 & 13 & 2 & 0 & 2 & 15 & 0 & 15 \\
\hline $50-55$ & 11 & 0 & 11 & 4 & 0 & 4 & 15 & 0 & 15 \\
\hline $55-60$ & 6 & 0 & 6 & 2 & 0 & 2 & 8 & 0 & 8 \\
\hline $60-65$ & 16 & 0 & 16 & 1 & 0 & 1 & 17 & 0 & 17 \\
\hline $65-70$ & 9 & 0 & 9 & 3 & 0 & 3 & 12 & 0 & 12 \\
\hline $70-75$ & 6 & 0 & 6 & 4 & 1 & 5 & 10 & 1 & 11 \\
\hline $75-80$ & 4 & 19 & 23 & 10 & 7 & 17 & 14 & 26 & 40 \\
\hline $80-85$ & 0 & 32 & 32 & 3 & 25 & 28 & 3 & 57 & 60 \\
\hline $85-90$ & 0 & 44 & 44 & 4 & 27 & 31 & 4 & 71 & 75 \\
\hline $90-95$ & 0 & 16 & 16 & 0 & 9 & 9 & 0 & 25 & 25 \\
\hline $95-100$ & 0 & 3 & 3 & 0 & 9 & 9 & 0 & 12 & 12 \\
\hline Total & 78 & 114 & 192 & 36 & 78 & 114 & 114 & 192 & 306 \\
\hline
\end{tabular}

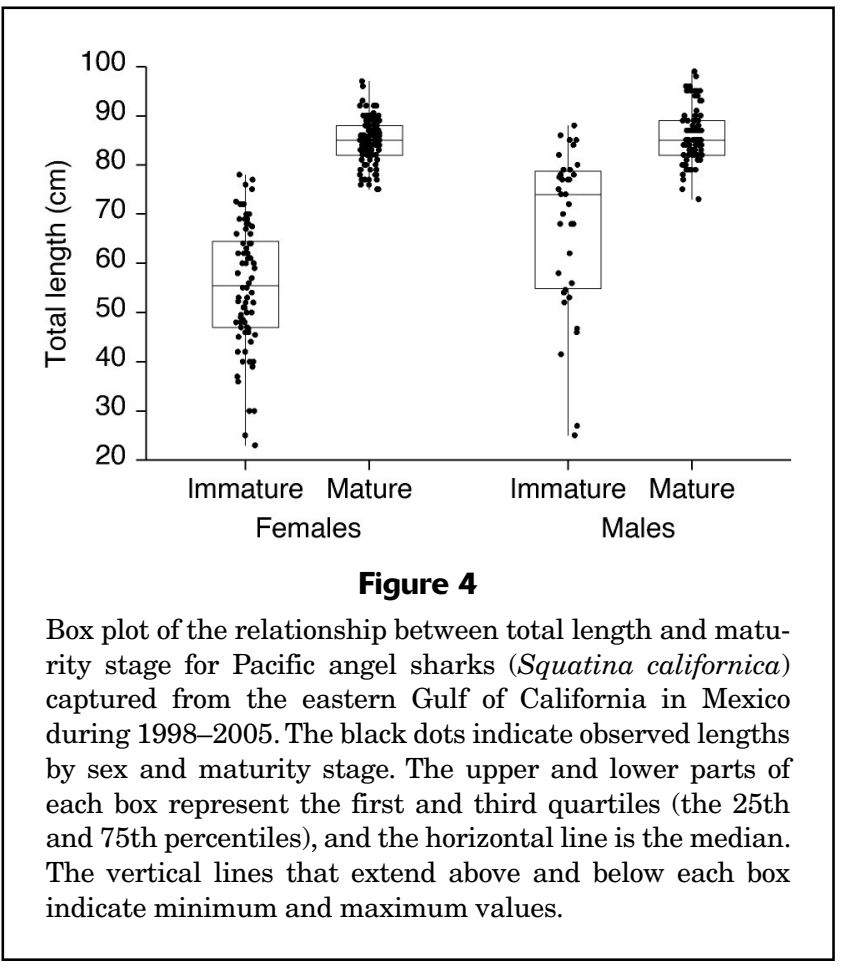

from the GOC. In addition, a latitudinal gradient in the maximum reported sizes of Pacific angel sharks has been observed, with sharks being larger on the coast of California and decreasing in length toward the southern part of the BCP on the Pacific coast. For instance, Miller and Lea (1972) reported a maximum length of $152.4 \mathrm{~cm}$ TL for individuals from the coast of California, and Natanson and Cailliet (1986) reported an $L_{50}$ of $107 \mathrm{~cm}$ TL for the same area $(\sim 70 \%$ of the maximum length). For individuals on the northern part of the BCP, Cartamil et al. (2011) reported lengths of 120-130 cm TL; whereas, Villavicencio-Garayzar (1996) reported a maximum length of $117 \mathrm{~cm}$ TL for individuals on the southern part of the BCP. Ramírez-Amaro et al. (2017) reported an unusually large size of $180 \mathrm{~cm}$ TL for individuals in this same area. For Pacific angel sharks in the Bay of La Paz, part of the GOC, Romero-Caicedo et al. (2016) reported that the largest sizes were $90-100 \mathrm{~cm}$ TL and estimated that the $L_{50}$ for males and females was 75.6 and $77.7 \mathrm{~cm}$ TL, respectively ( $77 \%$ of the maximum length). In contrast, in the study described here and conducted in Sonora and Sinaloa, the observed maximum length of Pacific angel sharks was $100 \mathrm{~cm}$ TL, and the estimated $L_{50}$ was $74.41 \mathrm{~cm}$ TL for females and $77.82 \mathrm{~cm}$ TL for males, values that correspond to $74 \%$ and $77 \%$ of the maximum length, respectively.

The frequency distribution of lengths at a given time can vary because of different factors, including selectivity of fishing gear and the seasonal availability of the species in the area. Differences in the length-frequency distributions of Pacific angel sharks in the GOC have been reported. In this study, a peak of abundance was found for the length class of 85-90 cm TL for both sexes. However, for both sexes, Romero-Caicedo et al. (2016) reported a peak of abundance for individuals that were $60-90 \mathrm{~cm}$ TL.

Female sharks often reach larger sizes than males (Castro, 2011), including sharks of the species smoothback angelshark (S. oculata) (Capapé et al., 2002), sawback 


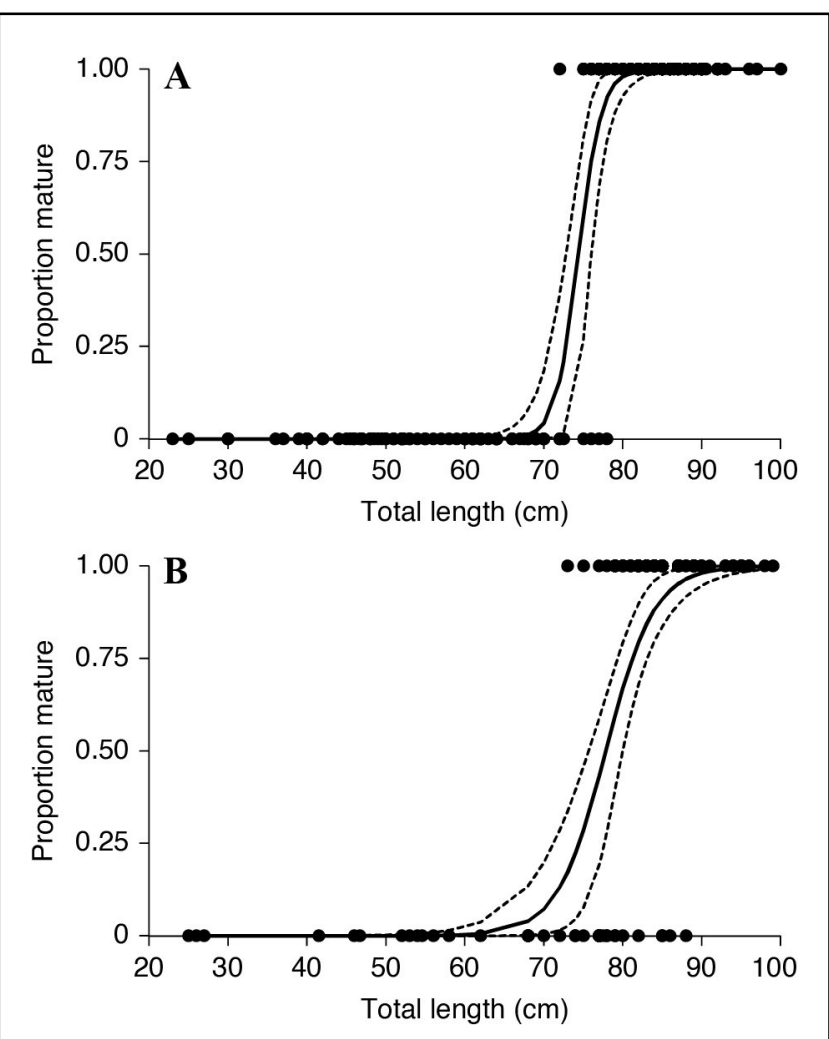

Figure 5

The proportion of (A) female and (B) male Pacific angel sharks (Squatina californica) that were mature, by total length, among those captured from the eastern Gulf of California in Mexico between 1998 and 2005. The dashed lines indicate the $95 \%$ confidence intervals of the estimated proportions from the logistic function.

angelshark (S. aculeata) (Capapé et al., 2005), and angular angel shark (S. guggenheim) (Colonello et al., 2007). However, at some point, the length structure of a stock can be altered by the level of historical exploitation (Stevens et al., 2000). Different factors, such as migration and gear selectivity, can influence the observed lengths in a sample. In particular, the effect of gear selectivity may be significant when interpreting life history characteristics and could distort growth curves and maturity ogives (Walker et al., 1998; Walker, 2005).

The artisanal elasmobranch fishery in the GOC is intense and has been developing for several decades (Bizzarro et al., 2009). It is likely that the maximum sizes between sexes are similar in this study because Pacific angel sharks no longer reach the sizes they had reached before exploitation became extreme. The level of exploitation in the GOC does not allow individuals to reach maximum size and affects the $L_{50}$.

Walker (2005) suggested that reported differences in length at maturity may also be a result of the criteria adopted to define maturity. In early studies of the biology of sharks, length at first maturity was based mostly on the smallest mature individuals in the sample (Branstetter,
1987). Such an approach fundamentally differs from the way $L_{50}$ is estimated by using a binary logistic regression (Walker, 2005, 2007). Technically, having insufficient data for the lengths of individuals that are in the transition in maturity from immature to mature hampers maximum likelihood estimation and makes estimation of the coefficients and 95\% CIs of the logistic function challenging (Christmann and Rousseeuw, 2001). The reproductive strategy of the Pacific angel shark, including vitellogenesis and the gestation period, can be understood only with systematic monitoring over time (Castro, 2009). Such monitoring can be challenging because some shark species are not available in fishing grounds year-round.

The incidental catch of Pacific angel sharks in artisanal and trawl fisheries in the GOC is concerning because of the low resilience of this species to fishing mortality (Cailliet et al., 1992). There are still gaps in our knowledge of the natural history of this species in the GOC; research needs include examination of seasonal migratory patterns and studies of age and growth. The estimate of $L_{50}$ from this study provides an important input to estimation of demographic characteristics. The maturity ogive produced by using a logistic function suitably represents the development pattern of this species because it describes maturity as a gradual process.

\section{Acknowledgments}

The Lucile and Packard Foundation and Instituto Nacional de Pesca y Acuacultura partially supported data collection. I thank L. González-Ania for review and advice on the results of the general linear model. I am grateful to C. Lozano-Alberú and M. Weber for their language editing. The comments and suggestions of 2 anonymous reviewers are much appreciated.

\section{Literature cited}

Bizzarro, J. J., W. D. Smith, R. E. Hueter, J. Tyminski, J. F. Márquez-Farías, J. L. Castillo-Géniz, G. M. Cailliet, and C. J. Villavicencio-Garayzar.

2007. The status of shark and ray fishery resources in the Gulf of California: applied research to improve management and conservation. Moss Landing Mar. Lab. Tech. Publ. 2009-01, 211 p.

Bizzarro, J. J., W. D. Smith, J. F. Márquez-Farías, J. Tyminski, and

R. E. Hueter.

2009. Temporal variation in the artisanal elasmobranch fishery of Sonora, Mexico. Fish. Res. 97:103-117. Crossref

Branstetter, S.

1987. Age, growth and reproductive biology of the silky shark, Carcharhinus falciformis, and the scalloped hammerhead, Sphyrna lewini, from the northwestern Gulf of Mexico. Environ. Biol. Fish. 19:161-173. Crossref

Cailliet, G. M., H. F. Mollet, G. G. Pittenger, D. Bedford, and

L. J. Natanson.

1992. Growth and demography of the Pacific angel shark (Squatina californica), based upon tag returns off California. Mar. Freshw. Res. 43:1313-1330. Crossref 
Cailliet, G. M., C. L. Chabot, M. C. Nehmens, and A. B. Carlisle. 2016. Squatina californica. The IUCN Red List of Threatened Species 2016: e.T39328A80671059. [Available from website.]

Capapé, C., A. A. Seck, A. Gueye-Ndiaye, Y. Diatta, and M. Diop.

2002. Reproductive biology of the smoothback angel shark, Squatina oculata (Elasmobranchii: Squatinidae), from the coast of Senegal (eastern tropical Atlantic). J. Mar. Biol. Assoc. U.K. 82:635-640. Crossref

Capapé, C., Y. Diatta, A. A. Seck, O. Guélorget, J. Ben Souissi, and J. Zaouali.

2005. Reproduction of the sawback angel shark Squatina aculeata (Chondrichthyes: Squatinidae) off Senegal and Tunisia. Cybium 29:147-157.

Cartamil, D., O. Santana-Morales, M. Escobedo-Olvera, D. Kacev,

L. Castillo-Geniz, J. B. Graham, and O. Sosa-Nishizaki.

2011. The artisanal elasmobranch fishery of the Pacific coast of Baja California, Mexico. Fish. Res. 108:393-403. Crossref

Castro, J. I.

2000. The biology of the nurse shark, Ginglymostoma cirratum, off the Florida east coast and the Bahama Islands. Environ. Biol. Fish. 58:1-22. Crossref

2009. Observations on the reproductive cycles of some viviparous North American sharks. Aqua 15:205-222.

2011. The sharks of North America, 640 p. Oxford Univ. Press, New York.

Christmann, A., and P. J. Rousseeuw.

2001. Measuring overlap in binary regression. Comput. Stat. Data Anal. 37:65-75. Crossref

Clark, E., and K. von Schmidt.

1965. Sharks of the central Gulf coast of Florida. Bull. Mar. Sci. 15:13-83.

Colonello, J. H., L. O. Lucifora, and A. M. Massa.

2007. Reproduction of the angular angel shark (Squatina guggenheim): geographic differences, reproductive cycle and sexual dimorphism. ICES J. Mar. Sci. 64:131-140. Crossref

Compagno, L. J. V.

1984. FAO species catalogue. Vol. 4. Sharks of the world. An annotated and illustrated catalogue of shark species known to date. Part 1. FAO Fish. Synop. 125, 249 p. FAO, Rome.

2005. Checklist of living chondrichtyes. In Reproductive biology and phylogeny of chondrichthyes: sharks, batoids and chimaeras (W. C. Hamlett, ed.), p. 503-548. Science Publishers Inc., Enfield, NH.

Escobar-Sánchez,O.,L.A.Abitia-Cárdenas, and F. Galván-Magaña. 2006. Food habits of the Pacific angel shark Squatina californica in the southern Gulf of California, Mexico. Cybium 30:91-97.

Escobar-Sánchez, O., F. Galván-Magaña, and L.A.Abitia-Cárdenas. 2011. Trophic level and isotopic composition of $\delta^{13} \mathrm{C}$ and $\delta^{15} \mathrm{~N}$ of Pacific angel shark, Squatina californica (Ayres, 1859), in the southern Gulf of California, Mexico. J. Fish. Aquat. Sci. 6:141-150. Crossref

Fouts, W. R., and D. R. Nelson.

1999. Prey capture by the Pacific angel shark, Squatina californica: visually mediated strikes and ambush-site characteristics. Copeia 1999:304-312.
Márquez-Farías, J. F.

2007. Reproductive biology of shovelnose guitarfish Rhinoba-

tos productus from the eastern Gulf of California México. Mar. Biol. 151:1445-1454. Crossref

Miller, D. J., and R. N. Lea.

1972. Guide to the coastal marine fishes of California. Calif. Dep. Fish Game, Fish Bull. 157, 235 p.

Natanson, L. J., and G. M. Cailliet.

1986. Reproduction and development of the Pacific angel shark, Squatina californica, off Santa Barbara, California. Copeia 1986:987-994.

Pittenger, G. G.

1984. Movements, distributions, feeding, and growth of the Pacific angel shark, Squatina californica, at Catalina Island, California. M.S. thesis, 83 p. Calif. State Univ., Long Beach, CA.

Ramírez-Amaro, S., D. Ramírez-Macías, R. Vázquez-Juárez, S. Flores-Ramírez, F. Galván-Magaña, and J. N. Gutiérrez-Rivera. 2017. Population structure of the Pacific angel shark (Squatina californica) along the northwestern coast of Mexico based on the mitochondrial DNA control region. Cienc. Mar. 43:69-80. Crossref

Romero-Caicedo, A. F., F. Galván-Magaña, A. Hernández-Herrera, and M. Carrera-Fernández.

2016. Reproductive parameters of the Pacific angel shark Squatina californica (Selachii: Squatinidae). J. Fish Biol. 88:1430-1440. Crossref

Stevens, J. D., R. Bonfíl, N. K. Dulvy, and P. A. Walker.

2000. The effects of fishing on sharks, rays, and chimaeras (chondrichthyans), and the implications for marine ecosystems. ICES J. Mar. Sci. 57:476-494. Crossref

Villavicencio-Garayzar, C. J.

1995. Distribución temporal y condición reproductiva de las rayas (Pisces: Batoidei), capturadas comercialmente en Bahía Almejas, Baja California Sur, México. Rev. Invest. Cient. Univ. Auton. Baja Calif. Sur (Ser. Cienc. Mar.) 6(1-2):1-12. [In Spanish.]

1996. Aspectos poblacionales del angelito, Squatina californica, en Baja California, México. Rev. Invest. Cient. Univ. Auton. Baja Calif. Sur (Ser. Cienc. Mar.) 7(12):15-21. [In Spanish.]

Walker, T. I.

1998. Can shark resources be harvested sustainably? A question revisited with a review of shark fisheries. Mar. Freshw. Res. 49:553-572. Crossref

2005. Reproduction in fisheries science. In Reproductive biology and phylogeny of chondrichthyes: sharks, rays and chimaeras (W. C. Hamlett, ed.), p. 81-127. Science Publishers Inc., Enfield, NH.

2007. Spatial and temporal variation in the reproductive biology of gummy shark Mustelus antarcticus (Chondrichthyes: Triakidae) harvested off southern Australia. Mar. Freshw. Res. 58:67-97. Crossref

Walker, T. I., B. L. Taylor, R. J. Hudson, and J. P. Cottier.

1998. The phenomenon of apparent change of growth rate in gummy shark (Mustelus antarcticus) harvested off southern Australia. Fish. Res. 39:139-163. Crossref 